\title{
Prometheus and the Degenerate: Arno Breker, Hans Bellmer, and Francis Bacon's Extreme Realism
}

\author{
Mark Featherstone $1 \square$ \\ Email m.a.featherstone@keele.ac.uk \\ Keele University, Keele, UK
}

\section{Abstract}

The abstract is published online only. If you did not include a short abstract for the online version when you submitted the manuscript, the first paragraph or the first 10 lines of the chapter will be displayed here. If possible, please provide us with an informative abstract.

The author considers the visualisation of the body under conditions of war through a discussion of two artists, the sculptor Arno Breker (1900-1991) and the surrealist Hans Bellmer (1902-1975), who imagined the fate of corporeality in Nazi Germany and beyond. He sets up the idea of National Socialism as an ocularcentric regime obsessed with spectacle and the experience of power where the powerful are seen and the weak, vulnerable, miserable, and centrally degenerate are not seen. It is possible to read Arno Breker's sculptures that imagine the idealised Aryan body as superhuman as a form of material dissimulation designed to hide or repress the criminal violence of National Socialism. While Breker imagines the ideal Aryan leading humanity into a future characterised by purity (e.g. his 1935 sculpture Prometheus), the other side of this dark utopian fantasy comprises the repression of the crime that the Nazi does not see or want to see. This criminal other side, it is argued, is revealed by the work of the surrealist Hans Bellmer, who famously opposed the Nazi's corporeal fantasy world through his Dolls project where the body is seen in its tortured, mutilated, violated, and destroyed real form. After exploring the politics of the Breker-Bellmer couple, and particularly the psychoanalytic dimensions of their opposition that may inform our understanding of body politics today, the author then goes on to compare both artists' works with Francis Bacon's rendition of 'humanity-as-meat' that both underpins and results from the workings of power, authority and neo-liberal capitalism alike.

\section{Keywords}

Nazi art

Nazism

Nietzsche

The abject

The real

Bare life

\section{The Anxious God}

Picking over the corpse of the dead God, modern man soon became his own God. But what kind of a God is this new Human God? Unlike the remote, untouchable God of the Old Testament, the modern God is a fragile, insecure being racked by anxiety. Ultimately, he knows what his predecessor could never know. He knows that he lacks transcendence or that his powers of transcendence (for instance, his ability to imagine the cosmos and project himself into outer space) are fatally limited by the existence of his animal body that he cannot escape. It is hard to be a God!

We can, of course, trace this tragic story back before the idea of the one God universe to the multi-God world of the Greeks, where Plato's Socrates bemoaned the existence of the body that would continue to constrain his reason until he finally escaped through the happy event of his execution famously captured by David in his iconic painting, The Death of Socrates. Fast forward to the origins of modernity itself, we know that Descartes (1984), perhaps the founder of modern scientism, sought to escape from the deceptive nature of the senses that connect the body to the world by engaging in the practice of radical critique (doubt). The objective of the method of doubt was to suspend the natural taken for granted knowledge of the body in favour of cognitive reason. Under these conditions Descartes reasoned that nothing was certain beyond what it was possible to establish on the basis of 
the powers of the mind. The body can always be deceived. Unfortunately, iDescartes realised that this strategy was ultimately insecure because he could not be certain that everything he knew, his very reason itself, was not the infernal scheme of some Demonic other set upon his deception. At this point, the early modern philosopher fell back upon the idea of a benevolent God, reasoning that if there was a Devil playing tricks upon him, it was likely that there was also a good God who would protect him from the Demon's machinations (O'Neill 1992). Bu hurtling into the new modern future, this theological position became unsustainable, and Nietzsche (1974), who had his Zarathustra proclaim the death of God to a group of rural idiots, saw that reason was not the answer. For Nietzsche the answer to the death of God and the collapse of transcendence was for man to overcome his abyssal anxiety and become the titanic overman capable of making his own way through life in a cold, dark meaningless universe.

Of course, Nietzsche knew that it is hard to be a God and constantly rise to the challenge of becoming. He was sensitive to the problems of his own God-making strategy and realised that not every man could become a titan. The majority would, unfortunately, seek out the security of the herd and lose themselves in what he would call, slave morality. Although the master would overcome slave morality and transvaluate the values of the crowd, Nietzsche understood that this would take an enormous struggle, a struggle that would never really end, and that this would define the life of the becoming overman. Centrally, Nietzsche thought that the overman should enjoy this struggle - it's what keeps him alive! - meaning that he tends to play down the problem of anxiety and its effects, which I think it is possible to employ as a kind of lens for ef looking back upon the horrors of what we might call the Nietzschean twentieth century. That is to say that we might take up the notion of the anxious overman, the anxious God of the moderns, and explore the horrors of the twentieth century through the psychohistory of this figure and his struggles to create himself in the void of the meaningless universe. Centrally, we might focus upon the modern God's obsessive defensiveness, his drive to create himself against a threatening outside, and explore the ways in which this approach to identity formation led to the emergence of a universe of extremes characterised by on the one hand, the search for invulnerable form and on the other hand, the production of destroyed formlessness, where the existence of the second state of abject formlessness essentially confirms the presence of the new God's total form. In the chapter that follows, I propose to explore this complex comprising the modern God's drive to create invulnerable form and the consequent emergence of abject formlessness through the lens of the plastic and visual arts. Through an exploration of particular cases drawn from art history my objective will be to show how the bottomless anxiety of the modern God, desperately in search of a secure sense of self, can be employed to understand the violent history of the twentieth century and the tendency towards atrocity and the creation of numberless, formless, abject others who could be destroyed in the name of the security of the new God who desperately wants to escape from his own human, all too human failings.

In this respect, I propose to explain atrocity in terms of the modern God's drive towards the creation of a kind of psycho-political imaginary that splits off in two directions defined by, on the one hand, utopian perfection, and on the other hand, dystopian despair, impurity, and degeneration. My use of the term imaginary in this context is deliberate, signalling a kind of imagined, fantastical construct, but also more precisely the Lacanian (2007) idea of ego construction where the pre-oedipal child first finds themselves in their own mirror image. Thus, the point of my reference to Lacanian psychoanalysis is first, to point to the importance of identity in my analysis, and more centrally the ways in which identity formation entails moving from a state of formlessness to a state of formal security premised upon estrangement and loss, and second, to connect this process of identity formation to the visualisation and visibility of the self which I propose to project into an exploration of representations of self and other in the arts. The related shift I make here is, of course, from the visualisation of the individual self, which in Lacanian theory objectifies itself in its own image, to a broader socio-cultural idea of identity formation in the plastic and visual arts, which I suggest project a vision of a kind of ideal type of cultural identity ("what we should be like') that then filters back towards the level of the individual who seeks to make or paint themselves in a cultural context defined by, in the case of Nietzschean modernity, anxiety and the deep-seated need to become an invulnerable God. In the case of modern European history, and particularly the German context, I think that it is possible to make the link between the individual level of the overman seeking to transform himself into a God and the socio-cultural level of what we might call political aesthetics through Wagner's idea of the gesamtkuntswerk, universal artwork, or total work of art which we might say sought to respond to the demise of God through the invention of a new mythology, religious image, or utopian ideal of society and man's role in its creation.

In this idea, which David Roberts (2011) explains we might use to understand the history of twentieth century Europe, the virtuous individual constructs their own identity in line with a social, political, economic, and cultural ideal which brings together utopian self and utopian society in a kind of synthetic total form that recalls Vitruvius' architectural vision of man in his environment and Leonardo's later image of Vitruvian man who perfectly occupies space. Building upon this idea of the body in space, and particularly the notion of the visual 
representation of the ideal self in the ideal society, in the work that follows I explore the case of what we might simultaneously consider the high and the low point of the modern problem of God-making, Nazi Germany. We might see the case of Nazism in terms of the high point of the movement towards modem God-making simply because the Nazi drive to steel the self against excremental others might be the most developed example of this stark political division between sacred and profane in the secular world. By contrast, Nazism represents the low point of this movement for exactly the same reason, which is that God-making necessarily entails the destruction of others who tend to provide evidence that the new God might not be everything they want to be, simply by virtue of their flawed humanity founded in their carnal participation in what we might call referring back to Lacan (2007, see Chapter 12, 'The Function and Field of Speech and Language in Psychoanalysis'), the real of existence. In order to try to capture this tension in the Nazi context, I refer to the cases of on the one hand Arno Breker, Hitler's favourite sculptor, who might see a kind of official representative of Nazi art who sought to carve and hammer the Reich's New Man out of stone, and on the other hand, the surrealist Hans Bellmer, whose deeply disturbing images of fragmented, abused, and destroyed dolls might be seen to represent the fate of the other body in Nazi Germany.

Although these two artists have been compared and contrasted before, most notably by Hal Foster (1991, 1995), what I want to emphasise in my reading is the necessary relationship between their works or more precisely their representations of the human body. In emphasising this dialectical tension, or identity of opposites, I want to move beyond the idea of Nazi fear outlined by Mark Neocleous (2005) in his work on Gothic Fascism. In this work Neocleous correctly points out that the Nazi or Fascist is defined by their fear of the other, but what he misses is the way in which the Nazi's dentity, his drive to become a God, is precisely what produces the monstrous other that torments him and constantly reminds him of his trauma and ruined sense of self. It is this unconscious tension that I want to capture in my reading of the relation between Breker's utopian sculptures of ideal bodies and Bellmer's dystopian representations of torn limbs by showing how Bellmer's horror shows might be seen to represent what Rosalind Krauss (1994) might call the optical unconscious of Breker's rock hard idealism. In this respect I suggest that the horror of Bellmer's fragmented bodies represents and enables us to see very precisely what the Nazi can 'not see' (note the slippage between the words Nazi and 'not see' which suggests National Socialism's blindness to the necessary relationship between self and other) which is the pointless violence and atrocity that is necessary to becoming a God from the fallen position of the miserable human being who must live and die as a body regardless of their desire to somehow become divine. Following this section of the chapter, which forms the centrepiece of my argument, in my conclusion I seek to move beyond the Nazi case to show how it is possible to understand the same body politics operative today through a comparison and contrast of on the one hand, the neoliberal capitalist utopia of work that appears to disappear the body beneath a blizzard of data and information and on the other hand, a consideration of Francis Bacon's images of the horror of the body which stage quite explicit attacks on symbols of transcendence, including the Pope, but less obviously men in blue suits who we might take for representatives of monstrous neoliberal managerial capitalism.

My point here is that Nazi idealism, and the more general aesthetic project of God-making, should not be seen in terms of a relic of the past or the first half of the twentieth century which was swept away by postmodernism, because this would be too easy. Although it is easy to not see the afterlives of Nazism, because it is more convenient to think that the violence and atrocity of the modern God-making was a German problem, this would be to learn nothing from the horrors of the camps. Instead, I want to suggest that we must look for continuity, which it is not particularly difficult to see when we use the lens of what Laurence Rickels (1991) calls American Germanicitv, and seriously consider Paul Virilio's (2006) idea that the Nazis lost the war, but won the peace: through the emergence of a kind of late capitalist political economic pitiless God-making project. Although late capitalist audiences are no longer captured and captivated by Breker's Nazi idealism, they have their own invulnerable superheroes and sports stars who seem similarly perfectly formed and provide the divine models for the neoliberal worker who labours under the empty fantasy that work will make them free ('Arbeit Macht Frei'), but is in reality ruined and destroyed in ways captured by Bellmer in his Nazi period images. It is not hard to find possible continuity between Nazism and what has followed in its wake in Ernst Junger's classic Nazi-era utopia, The Worker (2017), for example, which can be read equally as a historical piece of Futurist art or in more realist terms, a description of life under totally networked neoliberal capitalism in the contemporary global economy. Given the need to emphasise hidden continuity, this is precisely why I close the chapter through a discussion of Bacon's work because he can be seen to provide a connection between the Nazi twentieth century and the more general, transhistorical problem of God-making and the production of abject formlessness. Another way of capturing this relation is through the ideas of the sacred and the profane and the dialectical tension between the two terms, which I believe forms the visual unconscious, what we choose to 'not see', of the post-Nazi period and particularly the universe of contemporary neoliberal capitalism. This is what I think we can see in Bacon's work. However, before I turn to Bacon and the problem of atrocity in the neoliberal worker-state, I want to start with a 
comparison of the Nazi idealism embodied by Breker and the horrific surrealism or we might say materialism of Bellmer.

\section{Prometheus and the Degenerate}

In his book The Century (2007) Alain Badiou suggests that the defining feature of the twentieth century was the drive to create the New Man who would represent, and in a sense embody, the new modern society moving forward into the future. According to Badiou this drive to create the man of the future, the figure Freud (2010) called the Prosthetic God, was based in a paradoxical idea of voluntary historicism which meant that there was a kind of fatality about his emergence, but that the political aesthetic elite still had to make him appear. The figure of the New Man was, thus, a symbol of the Nietzschean idea of the will to power or the later Freudian concept of the unconscious that flows through and determines the behaviour of men and that they must learn to channel in the name of the future. However, in seeking to capture the political project of the New Man and the regimes that made God-making central to their vision of the world, Badiou moves beyond the language of the Nietzschean will to power and the Freudian unconscious to refer to Lacan's (2007) idea of the real which refers to the primitive state of nature that exists beneath first, the imaginary form of identity that humans construct when they look upon themselves in the mirror and start to think in terms of the estrangement of the image, and second, the symbolic order, where the self lives through desire and the pursuit of the satisfaction of lack which will theoretically make up for the original state of estrangement from the real. According to Badiou, the twentieth century was the century of the passion for the real, meaning that the major utopian experiments of this period were concerned with finding ways to expose the banalities of human life and somehow realise the essence of what lay beneath the meaninglessness of the everyday. In seeking out the real, Badiou explains that the Nazis, but the same applies to the Soviets, thought that they could overcome the anxiety-inducing lack inherent in existence itself and find a state of completion we might associate with the figure of God who knows no boundaries, outside or deficit of any kind. However, Badiou's point is that because complete purification is never possible, simply by virtue of the existential truth that the human is thrown into the world in a state of incompletion, the Nazis and other totalitarians found themselves caught in a state of endless struggle with others. In other words, utopia is never realised because there is always some other suspect, some other enemy, who explains why the self remains incomplete and the world is still out of kilter with itself.

In this way Badiou explains a century of struggle, a century of war, and a century of atrocity through the political pursuit of the real that could never be reached because, as Lacanian (2007) psychoanalysis explains, humans leave the real behind the moment they enter the world, where we should understand the idea of 'world' in phenomenological terms. According to Lacan's theory, there is no pure state of nature, no situation where man could find himself at complete peace, because the very nature of what it means to be human requires the structures of civilization, language, and other forms of technology. From the point of view of the human, there is no outside, no way to escape the separation between the universe of (1) the imaginary, where we conjure images of a unified self and a unified world, (2) the symbolic structures of civilization, where we always lack but imagine the possibility of being complete, and (3) the non-space of the real, which peeks through these structures suggesting that there is something more basic, more primal, more essential than the banality of the everyday. Of course, the irony of the Nazi and totalitarian efforts to reach the non-space of the real, which Žižek (1991) explains is itself a kind of fantasy generated by the lack of closure within the symbolic system of civilization, is that in many ways they managed to uncover this basic space of existence, but not in the ways that they imagined. In the case of the Nazis who I focus upon in this chapter, the intention was to access the real of a kind of Vitruvian body perfectly symmetrical with the cosmos and in this way transform men into Gods. However, the problem with this approach is that it necessarily took place on the level of the imaginary, which is precisely how we must understand the sculptures of the Arno Breker and Josef Thorak who hammered rock hard Aryan superheroes out of stone. The reason these figures closely conform to the Lacanian category of the imaginary is that they represented a kind of idealised, completed, Nazi self. They were, in a sense, God-making realised in stone. But the problem with this approach, and what Badiou misses in his book, is that taking this God-making strategy for an essential project which could somehow be completed or realised is precisely what produced the Lacanian real in the monstrous (mis)shape of the formless other who then needed to be annihilated in order to secure the imaginary (which was mistaken for the real) or reach some kind of essential level of reality where man and world are one.

In the Nazi universe the (un)truth of the Lacanian real would not, therefore, be about the fantastic monuments of Breker or Thorak, which we should understand through the idea of the imaginary, but rather the terrible others who the Nazis wanted to destroy (the Jew, the homosexual, the disabled person, and other degenerates) and actually went on to produce through the camps which stripped away the humanity of victims and survivors alike, leaving nothing left but what Giorgio Agamben (1998) calls bare life or we might say, pure existence crossing 
lover into death. This is where I think it is possible to find the real in the Nazi context, which is significant because it explains how they ended up producing the very thing they wanted to escape and reveals the psycho-politics behind their move to the industrialisation of atrocity and death. Given this thesis the reason the plastic art of the Nazi sculptors, including Breker and Thorak. becomes interesting is because they contributed to the creation of the Nazi imaginary, the fantasy world that generated the violence of the real and legitimated the extermination of those formless others who could not conform to the Party's idea of rock hard form. Indeed, in many respects exploration of sculpture is essential to understanding Nazi politics since there was very little difference between the methods of Breker and Thorak smashing ideal men out of stone with hammers and chisels and what the Nazi leadership sought to achieve through the creation of a utopian Germany free of degenerates and the waste of humanity. This is precisely how George Mosse (1996) understands Nazi gender politics, explaining that from the 1930s onwards Nazi culture valorised a masculine ideal concerned with heroism, sacrifice, and death to oppose the traumatic effects of defeat in World War I and the chaos of Weimar which was seen to embody the decadence and degeneration of the German people. In this view the tendency towards violence and atrocity in Nazi psychology emerges from deep trauma caused by the apocalyptic defeat of World War I and a sadistic drive to repair this wound by destroying others over and over again until finally, the damage of the past would disappear and there would be no more pain (Theweleit 1987, 1989).

Following this psychoanalytic thesis the historian Johann Chapoutot (2016) argues that the Nazis constructed a mythical world founded upon a vision of the Greeks and Romans to support their idea of the need to make modern Gods who would somehow heal the festering wounds of modern Germany. In this way, the Greek ideal became a historical fantasy figure who embodied what it would be like to live without damage and feel at home in the world (heimliche). The key mythological character in this fantasy became the titan Prometheus who stole fire from the Gods and essentially created human culture and civilization by virtue of the way he could provide an image of building a utopian future. Indeed, Prometheus the maker who crossed the boundary between the worlds of men and Gods became a favourite subject of Breker who created several sculptures of the titan through the 1930 s in the name of providing a model for the Nazi's New Man and the wider body politic or volkskorper. Building upon this explanation, we can refer to Eric Michaud (2004) who explores the centrality of the figure of Prometheus to Nazi culture, and expands upon the idea of aesthetic creation, suggesting that the core principles behind Nazi politics were idea and form. In Michaud's view these concepts conditioned understandings of race and the health of the people which were subordinate to the philosophical objective of founding a self-identical society, a kind of utopia beyond lack. For Michaud, Hitler, the failed artist who had suffered hysterical blindness upon returning from the front, thought that he could sculpt the masses on the basis of utopian ideas drawn from Plato and the Spartans, and that this would repair the wounds of the past by securing the Germans' place in the long history of the west. In this view, the Germans were the true heirs of the Greeks who were the founders of western civilization and the chosen people tasked with defending cultural history against the formlessness of the dark races.

Given this thesis, Hitler took the view that realising the beautiful form of the Reich would require updating the kind of ancient eugenics one finds in the Greek utopians by essentially cutting away the human waste responsible for the trauma of 1918. But beyond the apparent scientism of Nazi politics based in the social Darwinism of the period, what both Chapoutot and Michaud explain is the way that the Nazis leant on a utopian vision of ancient society and in this respect referenced a much broader movement around aesthetics and politics which Walter Benjamin (2003) would later identify in his work on fascism and art. Although the Nazis transformed this utopian vision into a fully formed ideology for the realisation of a master race and the annihilation of anybody considered degenerate, we can trace the origins of this aesthetic utopia back to the very origins of modern art history in Johann Winckelmann's (2006) book The History of the Art of Antiquity, published in 1764. In this work Winckelmann invented the idea of the Greek ideal running from the fifth through the fourth century BC defined by noble simplicity and calm grandeur and the notion of the fall towards modern formlessness which would influence the Nazi sculptors Breker and Thorak, but also potentially the Party's leadership which understood politics in terms of aesthetics and needed some sense of historical scale to measure the decay, decadence, and degeneration of the present. Of course, Winckelmann's vision of Greece was very particular, which becomes clear when we compare his idealism to Nietzsche's later version of the relationship between aesthetic form and formlessness and the project of God making from The Birth of Tragedy (1993) and Thus Spoke Zarathustra. (1974). Reading this work it becomes clear that the essential difference between Winckelmann's Greek ideal and Nietzsche's overman is that Nietzsche thought that the modern God must foster the Dionysian spirit of formlessness in the name of becoming, while this is precisely what Winckelmann was concerned to escape for what Nietzsche might have called Apollonian clarity and identity. While there is a sense in which Nietzsche's overman is about life, becoming, and movement into the future, Alex Potts (2000) explains that Winckelmann's stony idealism, and focus upon simplicity and calm, conjures visions of returning to the past and the nothingness of death. 
In Winckelmann's idea of the superiority of Greek form, freedom resides in completion, self-identity, and the lack of an outside. Winckelmann's utopian body is, therefore, a body on its own. It knows no other. By contrast, it is precisely Nietzsche love for Dionysus and the formless that suggests sympathy for the other and saves him from identification with Nazism, beyond his sister's schemes to transform her brother into a Nazi philosopher (Diethe 2007). However, Potts (2000) notes that where the other does appear in Winckelmann's history, for example, the famous sculpture Laocoon and His Sons which can be dated back to some point in the early first century BC, everything becomes about violence, struggle, and the battle to survive. In the case of Laocoon, the Trojan Priest fights to survive the attack of a monstrous serpent, leading Potts to suggest that his greatness resides in struggle. As the serpent sinks its fangs into Laocoon's thigh, he cries out. Agony is written across his face in a way that reflects the battle of modern man to rise above his anxiety in the bleak, Godless universe. Now this is perhaps where Nietzsche and Winckelmann cross in their common, tragic understanding of the struggle to create perfect form, with the difference that Nietzsche recognised that the overman was always a becoming. God, while Winckelmann seemed constantly conflicted about the possibility of form and the realisation of true freedom once and for all. Although this seems like a minor difference I think that it is essential for recognising the separation between Nietzsche and Nazism and understanding why the Nazis remained suspicious of Nietzsche's writings, a suspicion I would suggest was based upon his refusal to ever really force the identification of becoming and form. Where there is a very real sense of fear of collapsing form, formlessness, and castration in Winckelmann's idealism, this is more difficult to find in Nietzsche's work where the notion of becoming seems to preclude the possibility of the kind of eternally sealed being we find modelled in the sculptures of Breker and Thorak. I would suggest that the same is true when we compare Nietzsche's philosophy with the Proto-Fascist Junger who it is possible to argue developed Nietzsche's theory of the will to power through the 1920 s into the 1930 s.

According to Marcus Bullock (2012) writing on Junger's major philosophical work The Worker (2017), we can see the emergence of a new modern form of utopia in the theory of total mobilisation which concerns the ability of modern man to harness the technological storms of modernity. In Junger's theory, the high-tech world of modernity plunges man into a non-human maelstrom which he must shape through his work. As the subtitle of the book itself explains, man must exercise dominion and create form through his labour. Unlike Nietzsche, who looked towards the possibilities of formlessness, and centrally thought that the self was in a constant state of becoming, Junger's worker is only able to survive the violence of modernity because of his sculpted, hardened, body. His work-character means that he can live with the Cartesian violence, or what Junger calls abstract cruelty, of the new work-world where we must constantly exercise dominion and create form. As Junger himself explains, this new world is simultaneously hotter (because of the constant violence of formation), but also colder (in its absolute objectivity and indifference) than the old world, which is probably why he never lined up with the Nazis who wanted to hold onto the principle of racial superiority. However, even though Junger never made the leap from what Klaus Theweleit $(1987,1989)$ calls proto-fascism to Nazism, what his futurist utopia illustrates is the violence of what we might call aesthetic totalitarianism, which focuses upon the will to make form and centrally places the responsibility for the creation of the model, figure, or artwork in the hands of sculptor, who is somehow exempt from the problem of formlessness. In other words, the sculptor takes on the role of modern God, but never subjects himself to the same kind of challenge he poses to the formless mass.

Although Nietzsche saw that the Godless universe would lead to an obsession with form and formulation, his overman was arguably on the side of formlessness by virtue of his concern with endless becoming; leaving the herd to seek out the security of timeless form. Perhaps this is how we should understand Nazi and totalitarian politics, which exempt the master sculptor from the problem of formlessness and instead project this onto the other who must be destroyed in the name of security and the God-making project, in order to distinguish them from Nietzsche's philosophy? Where Nietzsche was concerned with overcoming the anxiety of formlessness in the name of becoming, the Nazi shrinks in the face of the abyss and projects his anxiety into attacks on the formless other which will appear to confirm his formal superiority. Thus we can see how Nietzschean struggle revolves around overcoming the self and the anxiety of the void, which clearly contrasts with Hitler's Kampf that was directed outwards and revolved around the sadistic attack on others in the name of resolving internal trauma, damage, and anxiety. This is why the Nazi will to form and will to utopia could not move beyond the slaughterhouse, space of death, dismemberment, and Nietzsche's God, Dionysus, which only led to the aggravation of the fear of formlessness that was thus endless (see Neocleous' concept of Gothic Fascism). Of course, the Nazis were aware that their struggle against formlessness would take time, hence Breker's monumental sculpture Perseverance, but they were also looking forward to the end, which is never the case with Nietzsche's philosophy. Regarding endings, what we might call Nazi formalism evoked on the one hand, the utopian future imagined by Breker, where the Aryan would be completely at home with himself, and on the other hand the kind of apocalyptic defeat evoked by the mythology of Thermopylae and Albert Speer's (2009; also see Featherstone 2005) theory of ruin value which concerned looking for permanence in the destroyed ruins of Reich. 
In this respect, the idea was that even and in fact especially in defeat, Nazi form would endure because there is no greater sense of closure than death itself.

What these funereal politics illustrate are the extreme lengths to which the anxious Gods of National Socialism were prepared to go in the name of the security of form. Hal Foster (1991) writes of this profound Nazi anxiety in his work on the fantasy of the armoured body which we find across the sculptures of Breker and Thorak and the writings of the Freikorps writers Von Salomon and Junger, not to mention Hitler's own scribblings. Following Theweleit's $(1987,1989)$ classic Male Fantasies, which describes the Nazis as walking terminations, Foster traces everything back to trauma and the attempt to overcome this through sadistic violence. But what he is less clear about is the way that the obsessive attempt to create form and the phobic fear of formlessness created a fatal situation where stable form became impossible and this fed back into the obsession with defence and persecution. Under these conditions the Nazi was no longer the sadistic aggressor attacking the other, but rather the victim of a global conspiracy leading Hitler to consistently compare the fate of Germany to the tortured body of Christ upon the cross. In this comparison Hitler linked the trauma of the Germans to the ultimate wound of God who sacrificed his only son to save humanity, but reversed the Christian imperative to love thy neighbour in the formation of conspiracy theory that could justify monstrous levels of violence. Inside Hitler's paranoid reality conditioned by megalomania and visions of persecution, the body horror of the German Christ set the scene for the body horror of the camps where Nazi scientists like Josef Mengele sought to understand the tolerances of the human body in the name of more efficient extermination and the realisation of the sculptures of Breker and Thorak in flesh and iblood.

However, what reference to Mengele shows is not only the way that the Nazi's aesthetic politics justified monstrous pseudo-science which, Virilio (2006) argues, itself shaded into a kind pitiless, abstract art defined by the drive to humiliate and destroy the body, but also how this strategy for the elimination of fragility and vulnerability in the name of ideal form constantly threw form itself into doubt by confronting the utopian ideal of total self-identity with its profane, miserable other - abject formlessness. In the case of Mengele, the notorious Angel of Death who worked at Auschwitz from 1943 to 1945, horrendous experiments on children focused on testing the limits of the body with the idea of finding ways to strengthen the Nazi form never produced anything but a ghoulish parade of bodies that confirmed that humans are not Gods, but rather flesh, blood, and bone and that what makes them divine is precisely their ability to overcome this finitude in compassion and sympathy for others. From this point of view it is easy to be a God when true transcendence does not imply the need to overcome finitude, or when one simply wants to annihilate the other who confirms that humanity can never escape its fleshy body, but much more difficult to sacrifice everything one has from a state of human, all too human finitude. Centrally, this is how I think we must understand the relationship between the works of Nazi artist of form Breker and perhaps the key surrealist of the formless body, Hans Bellmer whose disturbing images of dolls, contorted, and dismembered bodies provide a striking contrast to Breker's utopian figures and recall the violence of Mengele who tortured and destroyed for the sake of the Nazis' Apollonian idealism. Against Breker's monumental figures who clearly reflect the Lacanian (2007) category of the imaginary which describes the moment children point to their reflection in the mirror and imagine that the mirror image is who they are, Bellmer's bodies represent degeneration, psychotic breakdown, and corporeal regression towards the pre-oedipal state Lacan wrote about in terms of the body in pieces (corps morcele). In explaining the origins of the mutilated dolls which he produced through the 1930s, Sue Taylor (2002) points to Bellmer's rebellion against his father who was a Nazi sympathiser and engineer who worked exclusively with machines. According to Taylor, in staging psychotic attacks on his dolls Bellmer was looking to dismember the imaginary, patriarchal, fascist body of the father and return to the real self (though the tern 'self' would not really capture the reality of the real of existence) beneath this fabricated, ideal state which we might simultaneously connect to the death of the oedipal individual, but also a kind of maternal ethics that privileges the necessity of interaction, interrelation, and participation in the other.

Supporting this thesis, Taylor (2002) traces the origins of Bellmer's project back to the early 1930s when his mother passed him an old box of toys and the artist attended a performance of Offenbach's opera The Tales of. Hoffman, which interpreted the same story, The Sandman, that would later open Freud's (2003) paper on the uncanny and the horror of life-like machines. In Taylor's view the coincidence of these events, concerning nostalgia for childhood and fear of uncanny mechanisation, informed Bellmer's later symbolic attacks on his father and the phallic totally formed body and his related desire to return to mother. Contrasting Hitler's Christ, who became a symbol of trauma, betrayal, and need for revenge, Taylor points out that Bellmer's obsession with Matthias Grunewald's gruesome depiction of the crucifixion, The Isenheim Alterpiece, was focused upon the ecstasy of suffering and the destruction of the human form. In seeking to capture the meaning of God brought to earth in the transformed state of the suffering flesh and blood Christ on the cross, Jeremy Biles (2007) shows how Bellmer concentrated upon Grunewald's depiction of Christ's ruined hand precisely because our ability to 
use our hands to create tools is what makes us human and separates the human from the animal. Hands clawed in pain, Bellmer saw that Grunewald's Christ was not simply a representation of God in the miserable form of a man, but also man reduced to the status of the flesh, blood, and bone of the suffering animal that knows nothing but pleasure, pain, and instinct. In this respect, Grunewald's Christ became a model for Bellmer's dolls which were similarly concerned with the destruction of the self-identity of divine form and the return of humanity to the animality of what Georges Bataille (1992) would later call, continuous being. Indeed, Biles makes this idea of the attack on transcendence central to his theory of the relationship between Bellmer and Bataille, translating Pontius Pilate's declaration 'Ecce Homo' (Behold the Man) into Ecce Monstrum (Behold the Monster) in order to capture their common interest in. wounding in the name of the return to formlessness.

Of course, apart from signalling Pontius Pilate's presentation of Christ to the baying mob before his crucifixion, Biles' title 'ecce monstrum' also recalls Nietzsche's Ecce Homo (1992) where the philosopher opposes Dionysus to the Crucified who, in his view, was all about guilt-tripping and turning humanity into a neurotic species. However, Biles chooses to skip over Nietzsche's reading of Christ as a symbol of neuroses, guilt, and repression, in order to concentrate on what Bellmer and Bataille's miserable figure of Christ in agony shares with Dionysus, which is destruction, decline, and the collapse of the form of God into the formlessness of the animal. Against Nietzsche who writes of the overman, or the ubermensch who is more than human in his ability to handle anxiety, Biles suggests that Bellmer and Bataille offer the monstrous figure of the underman, or the untermensch who is less than human in his collapsing form which would otherwise separate him from the Lacanian real, but now ensures his communication and participation in continuous being. Recalling Bataille's (1985) own critique of the psychological structures of fascism from the early 1930s, which drew upon the opposition between the homogeneous and heterogeneous, what Biles reading of Bellmer and Bataille clearly captures is their opposition to the will to transcendence and what we have explained in terms of the Nazi obsession with the security of form that can never escape the abjection of the formless other. In Bellmer's art, but also Bataille's writings, this complex takes the form of what Biles calls cruxus mundi, or a crucified world, where the symbol of transcendence, God, is torn asunder and transformed into a miserable man who is no longer on the way to becoming God, but rather descends towards a state where it is no more than animal meat, screaming into the void.

\section{On Extreme Realism}

Expanding upon Taylor's and Biles' work on Bellmer's attack on form, Hal Foster $(1991,1995)$ explores the uncanny nature of Bellmer's dolls in terms of the critique of what he calls the becoming machine, or modern automaton which 'is me, but not me'. In this respect, Foster opposes Bellmer's project to Breker's imaginary figures who represent ideal objectifications of real men, but also a more general history of mechanisation, proletarianisation, and the destruction and dismemberment of bodies in the wheels of industrial technology. Thus Foster reads Bellmer out of his immediate context, Nazi Germany, where is it possible to oppose his work to the monumental formalism of Breker and Thorak to suggest his continued relevance to what we might call a new sociology in extremis, which would recall Bataille's own College of Sociology' (see Hollier 1988), focused upon understanding the interaction and interrelation between the polar opposites of form and formlessness, sacred and profane, ideal and material, and imaginary and real. While Bataille's College explored the tensions between these polarities in the 1930s, Foster's reading of Bellmer beyond the critique of Breker and Nazi utopianism opens the way for thinking about the way that the struggle between ideal form and abject formlessness remains of relevance for understanding the history of the post-war twentieth century. According to this position, which relies on Rickels' (1991) theory of the Germanicity of American capitalism that, for example, converted mass propaganda into consumer persuasion, and Virilio's (2006) contention that the post-humanism of Nazism easily translated into high-tech late capitalism where the body is dead weight to be sacrificed to the lightning speeds of a virtual future, the continuity between European totalitarianism and American globalisation is far more pronounced than the differences that the victors wanted to stress by pointing to the fundamental goods of political democracy and freedom. However, even the most basic reading of Junger's classic futurist work, The Worker (2017), reveals the continuity between Nazi ideal of the worker state (the work-world subsumes the work-character) where everybody pulls together for the fatherland and the contemporary neoliberal utopia which has always been in the process of becoming a kind of cybernetic fantasy of the subsumption of the individual in a superior workermachine from its origins in Mandeville through Smith up to Hayek (Featherstone 2017). Indeed, it is perhaps precisely Junger's sci-fi transgression of the really existing technological reach of the Nazi state that makes The Worker look like a fantastical utopia from the point of the 1930 s, but a strange prophetic commentary upon the depressing reality of high-tech capitalism from the point of view of the contemporary where everybody is sutured into the totally networked global economic form. Despite Milton Friedman's (2002) very public focus upon individual freedom in the 1960 s, the neoliberal worker has always been subject to the computational power and Cartesian violence of late capitalism and never really free of the kind of obiective violence Foucault Please make a final change here: change 'objective violence' to 'objective discipline'. The word violence is 
repeated in the sentence. (1977, 2010) wrote about throughout his works and Žižek (2009) focuses upon in his book, Violence.

Drawing on the work of Foucault and Žižek, I think it is possible to oppose Anson Rabinbach's (2018) theory of the end of the worker utopia in the new totally networked society. In his book, The Eclipse of the Utopias of Labour Rabinbach's thesis amounts to saying that because high-tech workers tend to sit behind desks and rely on brain power over muscle power, they no longer occupy a utopia of work of the kind outlined by Junger. On the one hand, Rabinbach has a point because it may be far more difficult now than ever before for the high-tech prole to convert their labour into work in the form of Marxist-Sartrean praxis that would set them free, but on the other hand I think he completely misses the point about the way late capitalism is actually the realisation of the kind of dark utopia of total work imagined from the very origins of capitalism through the totalitarian twentieth century. Although Badiou (2007) makes the point that post-war capitalism sought to escape the totalitarian obsession with uncovering the real by confining itself to the banality of number - quantitative measure dictates every decision from the value of art to the meaning of the good decided in elections-he also misses the way in which this (apparently restrictive) focus upon numbers develops its own vision of beauty, symmetry, and form that is completely unable to tolerate the formlessness of human life and the human body. Whereas in the Nazi case everything became about Aryan form and the ethnic utopia, and Hitler's thanatological political project would stop at nothing to realise this objective, late capitalism takes up the cause of the God of the bottom line (profit) and the death drive towards unlimited growth in the context of a planet which is, like the miserable creatures that inhabit its fragile environments, finite.

Of course, in much the same way that the body was everywhere in Nazi Germany, and one could not escape visions of on the one hand Breker's mass-produced Promethean supermen and on the other hand endless propaganda images of monstrous degenerates, Adorno and Horkheimer (1997) would explain that capitalism has its own corporeal fantasy world comprising invulnerable superheroes (Captain America, Iron Man) for the kids, hard running sports stars (Ronaldo, Tom Brady) for fathers, and an endless procession of celebrities who are superhuman by virtue of nothing more than having made it onto the screens of the global media for the masses. On the other side of the contemporary late capitalist fantasy world we find the miserable bodies of the war-tom (the refugee, the abused, and a host of other 'losers' to use the language of the American President) that belong to nobody and who we tolerate because they are victims of the complete indifference and objectivity of number under conditions of economic totalitarianism. Now it is for this reason that Virilio (2006) writes of pitiless art, the logic of disappearance into high-tech speed, and the humiliation of the body before the God of the virtual form, and I want to conclude by looking towards the art of Francis Bacon, who it is possible to say connects the violence of Nazism to a much more general tendency towards disappearance, humiliation, and imaginary formalisation operating in western (art) history and taking in the dreamworlds of contemporary neoliberal capitalism. Martin Hammer (2012) makes this point in his work on Bacon and Nazi propaganda, explaining that Nazi symbolism is a key theme throughout Bacon's work, where form is constantly and violently dissolving towards formlessness. Akin to Bellmer, who drew upon religious symbolism to undermine the conceit of transcendence, Bacon famously imagined the scene of the crucifixion in order to suggest the miserable profanity of Christ and the lack of potential for redemption in a Godless universe.

In Bacon's paintings humans are meat, nothing more, nothing less, and he focuses upon transcendent figures (Christ, the Pope) to illustrate this precisely because their will to transcendence, their will to overcome their animality, throws into relief and highlights their decline towards the immanence of bare life or the profane real of existence. In this respect it is possible to argue that Bacon's work was driven by a desire to explode the imaginary screens that legitimate violence by connecting it to some transcendent end or telos (form, ethnic purity, number, efficiency) in order to expose the atrocity of the real and the slaughterhouse of history. In much the same way that Bellmer's art was a protest against his authoritarian father, we find a similar motivation lurking behind Bacon's work which might be interpreted in terms of Anti-Oedipal rebellion against a father who could not tolerate his son's homosexuality and threw him out of the family home. Cast out of his home by a violent patriarch, an event that we might understand symbolically through the Freudian complex of the (un)heimliche (home/unhome) (see Freud 2003), the estranged Bacon appeared to see through every sociological frame that might normalise violence and made use of this vision in order to paint of the real of the formless body. Despite the various frames and screens we use to defend violence, Bacon's sympathy lay with flesh, blood, and bone, noting his identification with slaughtered animal carcases in his interviews with David Sylvester (2016) and capturing the base sensation of being meat in a number of paintings, including Figure with Meat (1954) where the Pope sits between two halves of a carcass. In this work Bacon opposes the transcendent form of Papal authority with abject, formless, meat and it is precisely this tension, the tension exposed in what Martin Harrison (2006) calls Bacon's extreme realism, which Gilles Deleuze (2005) takes up in his book on the artist, The Logic of Sensation. 
According to Deleuze, the central tension in Bacon's work is between form and flesh, endlessly captured in images of bodies escaping from themselves in the kind of violent spasms that leads Armin Zweite (Zweite and Muller 2006) to write of the constant liquefaction of the body. The effect of these violent processes is, in Bacon's own words, the revealing of the brutality of fact beyond the screens, frames, and forms that otherwise provide life with transcendent meaning. In this way, Bacon's art has the potential to break through the dangerous imaginaries of Nazi art (Breker) and neoliberal culture (number) to reveal the horrors and atrocities produced in the name of these frames of understanding. While Bacon's real is meaningless and nihilistic in itself and his body is utterly profane and formless on its own terms, the extreme consequences of this condition only emerge in relation to the violent pursuit of transcendence and form. It is, therefore, the tension between form and formlessness, between Breker and Bellmer in the Nazi case that produces Bacon's untermensch who occupies the space Deleuze (2005) calls the 'zone of indiscernibility' between man and animal where the interrelation between flesh and bone that creates form collapses towards the abjection of meat. Writing on the body as formless meat, Deleuze points to the importance of the mouth in Bacon's figures, explaining that their screams symbolise their descent into the state of animality without abstract language. As they howl into the existential void, Rina Arya (2012) notes that Bacon's figure recalls the predicament of Nietzsche's Zarathustra and Sartre's Antoine Roquentin, who were similarly unable to believe in the various forms of transcendence put before them. Against all forms of verticality from religion (most famously, his 1953 painting Study After Velazquez's Portrait of Pope [Innocent X]) through to postwar capitalism (I would interpret, Bacon's various images of men in blue as critiques of the existential void of business and the men who coldly manipulate numbers), it is clear that Bacon was opposed to the kind of brutal, post-human formalism we see in Breker's monumentalism and the late capitalist idealism of the beauty of number simply because of the violence and atrocities these forms inflict upon formless bodies.

Akin to Bellmer, whose dolls symbolised violent rebellion against the father in the name of the degenerate and other monsters, Bacon's work evokes sympathy for the bare life of Deleuze and Guattari's (1987) schizophrenic body without organs, in a Godless world where the temptation is to try to escape the anxiety of vulnerability into the impossibility of absolutely secure form. Since this is an impossible fantasy, an imaginary frame, it generates an extreme situation conditioned by the absolute opposition of the sacred and the profane, hubris and humiliation, and Prometheus and the Degenerate, where we tend to 'not see' violence and atrocity. But by focusing on the other side of this Lacanian social relation, what Robert Buch (2011) calls the pathos of the real, Bellmer and Bacon expose the terror of form we can see in Breker and other transcendental imaginaries for the sake of the existential liberation of the formless body, which is always meat - nothing more, nothing less.

\section{References}

Adorno, T., \& Horkheimer, M. (1997). Dialectic of Enlightenment. London: Verso.

Agamben, G. (1998). Homo Sacer: Sovereign Power and Bare Life. Stanford: Stanford University Press.

Arya, R. (2012). Francis Bacon: Painting in a Godless World. Farnham: Lund Humphries.

Badiou, A. (2007). The Century. Cambridge: Polity.

Bataille, G. (1985). Visions of Excess: Selected Writings, 1927-1939. Minneapolis: University of Minnesota Press.

Bataille, G. (1992). Theory of Religion. New York: Zone Books.

Benjamin, W. (2003). The Work of Art in the Age of Its Technological Reproducibility: Third Version. In Selected Writings: Volume IV: 1938-1940 (pp. 251-283). Cambridge, MA: Harvard University Press.

Biles, J. (2007). Ecce Monstrum: Georges Bataille and the Sacrifice of Form. New York: Fordham University Press.

Buch, R. (2011). The Pathos of the Real: On the Aesthetics of Violence in the Twentieth Century. Baltimore: Johns Hopkins University Press.

Bullock, M. (2012). Flight Forward: The World of Ernst Junger's Worker. Utopian Studies, 23(2), 450-471. 
Chapoulot, J. (2016). Greeks, Romans, Germans: How the Nazis Usurped Europe's Classical Past. Oakland: University of California Press.

Deleuze, G. (2005). Francis Bacon: The Logic of Sensation. Minneapolis: University of Minnesota Press.

Deleuze, G., \& Guattari, F. (1987). A Thousand Plateaus. Minneapolis: University of Minnesota Press.

Descartes, R. (1984). Discourse on Method and the Meditations. London: Penguin.

Diethe, C. (2007). Nietzsche's Sister and the Will to Power: A Biography of Elisabeth Forster-Nietzsche. Urbana: University of Illinois Press.

Featherstone, M. (2005). Ruin Value. Journal for Cultural Research, 9(3), 301-320.

Featherstone, M. (2017). Planet Utopia: Utopia, Dystopia, and Globalisation. London: Routledge.

Foster, H. (1991). Armor Fou. October, 56(Spring), 64-97.

Foster, H. (1995). Compulsive Beauty. Cambridge: MIT Press.

Foucault, M. (1977). Discipline and Punish: The Birth of the Prison. London: Penguin.

Foucault, M. (2010). The Birth of Biopolitics: Lectures at the College de France, 1978-1979. New York: Picador. Freud, S. (2003). The Uncanny. London: Penguin.

Freud, S. (2010). Civilization and Its Discontents. New York: W. W. Norton.

Friedman, M. (2002). Capitalism and Freedom. Chicago: University of Chicago Press.

Hammer, M. (2012). Francis Bacon and Nazi Propaganda. London: Tate Publishing.

Harrison, M. (2006). Francis Bacon: Extreme Points of Realism. In A. Zweite \& M. Muller (Eds.), Francis Bacon: The Violence of the Real (pp. 37-55). London: Thames and Hudson.

Hollier, D. (1988). The College of Sociology, 1937-39. Minneapolis: University of Minnesota Press.

Junger, E. (2017). The Worker: Dominion and Form. Evanston: Northwestern University Press.

Krauss, R. (1994). The Optical Unconscious. Cambridge: MIT Press.

Lacan, J. (2007). Ecrits. London: Verso.

Michaud, E. (2004). The Cult of Art in Nazi Germany. Stanford: Stanford University Press.

Mosse, G. (1996). The Image of Man: The Creation of Modern Masculinity. Oxford: Oxford University Press.

Neocleous, M. (2005). Gothic Fascism. Journal for Cultural Research, 9(2), 133-149.

Nietzsche, F. (1974). Thus Spoke Zarathustra. London: Penguin.

Nietzsche, F. (1992). Ecce Homo: How One Becomes What One Is. London: Penguin.

Nietzsche, F. (1993). The Birth of Tragedy: Out of the Spirit of Music. London: Penguin.

O’Neill, J. (1992). Mecum Meditari: Descartes Demolishing Doubt, Building a Prayer. In Critical Conventions: 
Interpretation in the Literary Arts and Sciences (pp. 222-234). Norman: University of Oklahoma Press.

Potts, A. (2000). Flesh and the Ideal: Winckelmann and the Origins of Art History. New Haven: Yale University Press.

Rabinbach, A. (2018). The Eclipse of the Utopias of Labor. New York: Fordham University Press.

Rickels, L. (1991). The Case of California. Baltimore: Johns Hopkins University Press.

Roberts, D. (2011). The Total Work of Art in European Modernism. Ithaca: Cornell University Press.

Speer, A. (2009). Inside the Third Reich. London: Phoenix.

Sylvester, D. (2016). Interviews with Francis Bacon: The Brutality of Fact. London: Thames and Hudson.

Taylor, S. (2002). Hans Bellmer: The Anatomy of Anxiety. Cambridge: MIT Press.

Theweleit, K. (1987). Male Fantasies, Volume I: Women, Floods, Bodies, History. Minneapolis: University of Minnesota Press.

Theweleit, K. (1989). Male Fantasies, Volume II: Male Bodies-Psychoanalyzing the White Terror. Minneapolis: University of Minnesota Press.

Virilio, P. (2006). Art and Fear. London: Continuum.

Winckelmann, J. (2006). History of the Art of Antiquity. Los Angeles: Getty.

Žižek, S. (1991). Looking Awry: An Introduction to Jacques Lacan Through Popular Culture. Cambridge: MIT Press.

Žižek, S. (2009). Violence. London: Profile Books.

Zweite, A., \& Muller, M. (2006). Francis Bacon: The Violence of the Real. London: Thames and Hudson. 